\title{
Pandemi Covid-19: Dampak terhadap Pekerjaan Konstruksi
}

\author{
Anggi Nidya Sari ${ }^{1 *}$, Viktor Suryan ${ }^{2}$ \\ ${ }^{1}$ Politeknik Negeri Sriwijaya, \\ ${ }^{2}$ Politeknik Penerbangan Palembang \\ *Correspondence email: angginidya @polsri.ac.id
}

\begin{abstract}
Abstrak. Pandemi Covid-19 telah menyebar sejak ditemukan kasus pertama di Indonesia pada tahun 2020 dan memberikan pengaruh disegala aspek kehidupan diseluruh dunia, termasuk industri konstruksi. Pemerintah mengeluarkan aturan mengenai Pembatasan Sosial Berskala Besar (PSBB) sehingga membatasi pekerja konstruksi untuk beraktifitas diluar rumah. Hal ini memberikan dampak yang signifikan terhadap pekerjaan konstruksi. Tujuan penelitian ini yaitu untuk mengetahui seberapa besar pengaruh Pandemi Covid-19 terhadap proyek konstruksi, baik dampak terhadap proyek atau personil. Metode yang digunakan pada penelitian ini yaitu metode kuantitatif deskriptif dengan menggunakan pendekatan analisis data sekunder, yaitu dengan menyebarkan kuisioner kepada sejumlah responden, untuk kemudian dihitung persentase dari jawaban tiap responden. Berdasarkan hasil penelitian, diketahui bahwa dampak Covid-19 terhadap pekerjaan konstruksi yaitu 78,9\% proyek konstruksi mengalami penundaan. Alasan utama adanya penundaan disebabkan oleh pendanaan yang terbatas dan pemberlakuan PSBB (Pembatasan Sosial Berskala Besar) dengan masing-masing persentase sebesar 53,8\% dan 29,6\%. Selain itu, dampak pada para personil yaitu aktifitas menjadi terbatas $(64,22 \%)$ dan komunikasi menjadi tidak lancar $(24,77 \%)$.
\end{abstract}

Kata Kunci: Covid-19, Pandemi, Konstruksi.

\section{PENDAHULUAN}

Wabah Corona (Covid-19) yang merebak diseluruh dunia saat ini memberikan pengaruh yang signifikan di segala bidang seperti bidang Ekonomi, Pariwisata, dan Pendidikan. Pergerakkan perdagangan barang dan jasa menurun sangat ekstrim akibat di berlakukannya Pembatasan Sosial Skala Besar (PSBB). PSBB membatasi mobilitas untuk masuk ke daerah satu dan ke daerah lainnya. Hal ini menjadi salah satu penyebab mundurnya pekerjaan konstruksi. Material yang digunakan untuk mengerjakan suatu proyek tidak dapat dihadirkan tepat waktu. Begitupun dengan jumlah anggaran, secara nasional banyak anggaran di relokasi ataupun di rasionalisasi untuk pengangan Covid-19.

Imbas dari Covid-19 juga berdampak pada penjualan perumahan. Pada rentang tertentu selama pandemik banyak pembangunan perumahan yang terhenti karena anggaran yang dialokasikan pada kebutuhan lainnya yang lebih menjadi prioritas. Pada saat pandemi memang masih ada proyek yang tetap berjalan, pekerjaan konstruksi yang tetap dijalankan merupakan proyek prioritas terutama proyek-proyek fasilitas untuk mendukung penanganan dan pencegahan Covid-19, seperti pembangunan rumah sakit, penyedia air bersih, dan tempat cuci tangan.

Penelitian ini diharapkan dapat memberikan informasi mengenai seberapa besar dampak Covid-19 terhadap dunia konstruksi dan apa penyebab paling dominan yang mempengaruhi pekerjaan konstruksi di masa pandemi.

Menurut Hasan dkk (2016), ada beberapa faktor penyebab keterlambatan proyek konstruksi yaitu: kekurangan bahan konstruksi, perubahan material pada bentuk, fungsi dan spesifikasi, serta terlambatnya pengiriman barang. Metode yang digunakan pada penelitian ini ialah metode rangking dengan memberikan prioritas terhadap variabel studi.(Hassan et al., 2016). Pada lingkup proyek Pemerintah ada 3 faktor utama yang mempengaruhi keterlambatan yaitu, cuaca, pekerja dan desain (Kurniawan dkk, 2018)

Penelitian yang dilakukan oleh Andi Maddeppungen, Dwi Esti Intari, dan Aulia Oktafiani membahas masalah faktor penyebab keterlambatan proyek pembangunan 6 ruas jalan tol dalam Kota Jakarta. Metode yang digunakan adalah Metode Rangking dengan menyebarkan kuisioner sebanyak 50 variabel yang diajukan kepada 50 responden. Pengolahan data dilakukan dengan bantuan software SPSS v.25. Dari perhitungan diketahui bahwa faktor utama penyebab keterlambatan proyek adalah kurangnya keahlian tenaga kerja (Maddeppungeng dkk, 2020).

Pengaruh pandemik Covid-19 terhadap perekonomian Indonesia antara lain: pemutusan hubungan kerja, penurunan PMI manufaktur (Yamali \& Putri, 2020). Beberapa sektor seperti pariwisata, perdagangan serta investasi mengalami dampak buruk secara langsung (Nasution dkk, 2020). Dengan menggunakan metode kuantitatif deskriptif dan data sekunder diketahui bahwa dampak Covid-19 menyebabkan rendahnya sentiment investor terhadap pasar. Dengan berkembangnya kasus Covid-19 yang semakin banyak mengakibatkan pasar lebih berfluktuasi ke arah negatif. Berdasarkan analisis sensitivitas diketahui pula bahwa lambannya ekonomi global juga menyebabkan melambatnya ekonomi Indonesia (Nasution dkk, 2020).

Hadiwardoyo (2020) melakukan penelitian mengenai kerugian ekonomi nasional akibat Covid-19. Pembatasan aktivitas akibat adanya pandemik Covid-19 mengakibatkan kerugian ekonomi secara nasional. Semakin lama diberlakukannya Pembatasan Sosial Berskala Besar (PSBB) dampak kerugian akan semakin membesar. Dalam 
penelitian ini pembahasan kerugian dibagi dalam beberapa kelompok, yaitu kelompok kerugian nasional, sektoral, corporate dan individu. Metode yang digunakan pada penelitian ini yaitu dengan menggunakan pendekatan kualitatif fenomenologi. Dari penelitian disimpulkan bahwa negara harus hadir dlam memberikan dukungan atau subsisdi agar rakyat berpenghasilan rendah tetap produktif (Hadiwardoyo, 2020).

Gamil \& Alhagar (2020) mengungkapkan bahwa ada beberapa dampak Covid-19 di bidang konstruksi yaitu penangguhan proyek, tenaga kerja yang kehilangan pekerjaan, pekerjaan yang melebihi batas waktu, biaya yang berlebihan, dan dampak keuangan. Penelitian ini juga menjabarkan konsekuensi terjadinya pandemik secara tiba-tiba dan membantu para pemegang proyek untuk menyiapkan skenario terburuk dalam tahap perencanaan proyek (Gamil \& Alhagar, 2020).

Jallow dkk (2020) mengemukakan perubahan yang harus dilakukan pada sektor infrastruktur agar tetap mematuhi protokol kesehatan dan tetap produktif saat lockdown. Penelitian ini dilakukan dengan metode kualitatif. Penelitian ini dilakukan dengan menggunakan analisis tematik. Hasil dari penelitian ini memperlihatkan bahwa sulit mengelola proyek saat para pekerja harus bekerja dari rumah. Hal ini menyebabkan beberapa pekerjaan tertunda karena para pekerja tidak dapat memeriksa pekerjaan fisik dilapangan. Namun untuk meminimalisir penundaan, digunakan beberapa teknologi seperti rapat online dan untuk memvisualisasikan permodelan bangunan dengan menggunakan visualisasi 3D saat rapat secara online (Jallow dkk, 2020).

\section{METODE}

Pada penelitian ini metode yang digunakan adalah metode kuantitatif deskriptif. Menurut (Russefendi, 2010) penelitian deskriftif adalah penelitian yang menggunakan pengamatan, wawancara atau kuisioner mengenai keadaan saat ini, mengenai subjek yang sedang diteliti. Melalui wawancara atau angket yang disebar kita mengumpulkan data untuk menjawab permasalahan yang sedang diteliti. Pada metode kuantitatif deskriptif pendekatan yang digunakan adalah analisis data sekunder (Sugiyono, 2016).

Pada penelitian ini data diperoleh dengan cara menyebarkan kuisioner pada mereka yang pekerjaannya di bidang konstruksi, seperti kontraktor, konsultan, dan lain-lain.

Data yang telah diperoleh dari kuisioner yang telah disebarkan disajikan dalam bentuk pictogram, diagram batang dan disajikan pula dalam bentuk tabel.

Diagram alir penelitian dapat di lihat pada gambar di bawah ini:

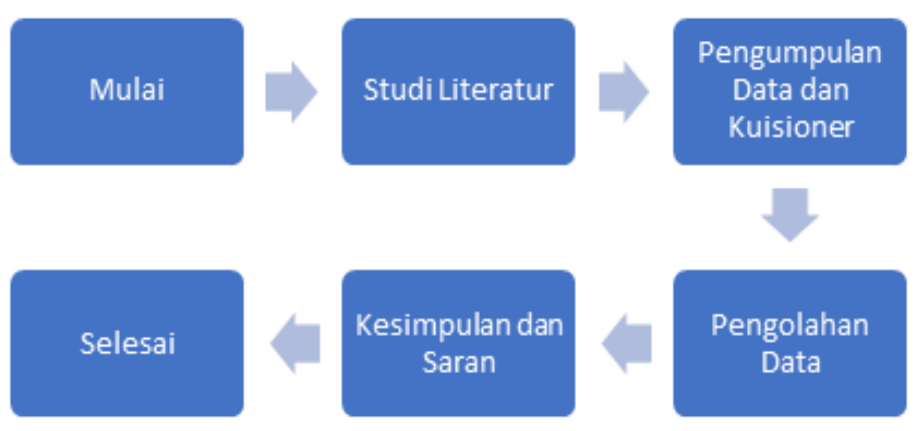

Gambar 1. Diagram Alir

\section{HASIL}

Hasil berisi jawaban dari permasalahan penelitian secara kuantitatif dan/atau kualitatif secara jelas, tepat dan lengkap yang dapat menggunakan informasi dalam bentuk gambar/grafik/tabel/uraian secara aktual. Setiap hasil dalam penelitian harus di bahas dan dibandingkan dengan teori dan penelitian sejenis. (Times new Roman Spasi 1.5).

Jumlah responden yang diperoleh dari penyebaran kuisioner adalah 166 responden dengan 201 Jenis pekerjaan. Semua responden memiliki pekerjaan dibidang konstruksi. Setiap responden memiliki minimal satu atau beberapa pekerjaan di bidang konstruksi. Jenis pekerjaan/posisi pekerjaan tersebut dapat dilihat pada Tabel 1 di bawah ini

Tabel 1. Jenis Pekerjaan/Posisi dalam Pekerjaan Konstruksi

\begin{tabular}{clcc}
\hline No & \multicolumn{1}{c}{ Pekerjaan/Posisi } & Jumlah & Persentase (\%) \\
\hline 1 & Pemilik Pekerjaan/Pejabat Pembuat Komitmen (PPK). & 54 & 26,9 \\
2 & Pelaksana Pekerjaan/ Kontraktor & 40 & 19,9 \\
3 & Perencana Pekerjaan/ Konsultan & 34 & 16,9 \\
4 & Pengawas Pekerjaan/ Konsultan & 39 & 19,4
\end{tabular}




\begin{tabular}{rlcc}
5 & Pendamping/ Fasilitator Desa & 30 & 14,9 \\
6 & Pekerjaan Konstruksi Lainnya & 4 & 2,0 \\
\hline & Jumlah & $\mathbf{2 0 1}$ & $\mathbf{1 0 0}$ \\
\hline
\end{tabular}

Sumber: Data Olahan (2020)

Dari Tabel 1 diketahui bahwa terdapat 6 jenis pekerjaan atau posisi pekerjaan dari 166 responden. Posisi pekerjaan terbanyak adalah posisi pemilik pekerjaan/Pejabat Pembuat Komitmen (PPK), yaitu sebesar 26,9\%. Tiap responden memiliki paling tidak 1 atau lebih pekerjaan di bidang konstruksi, berdasarkan data yang diperoleh diketahui bahwa jumlah responden yang memiliki pekerjaan lebih dari 5 yaitu 25,9\% dari total keseluruhan pekerjaan sebanyak 221 pekerjaan. Jumlah pekerjaan dan klasifikasi pekerjaan responden dapat dilihat pada Grafik dan Tabel di bawah ini:

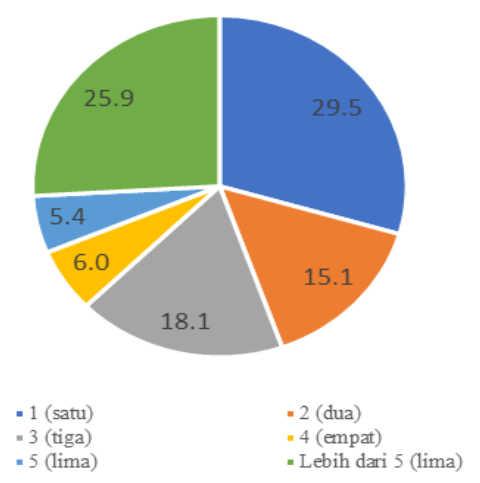

Gambar 2. Jumlah Pekerjaan Responden di bidang Konstruksi Tahun 2020

Tabel 2. Klasifikasi Pekerjaan Konstruksi Responden Tahun 2020

\begin{tabular}{clcc}
\hline No & \multicolumn{1}{c}{ Pekerjaan/Posisi } & Jumlah & Persentase (\%) \\
\hline 1 & Bangunan Gedung & 69 & 31,2 \\
2 & Bangunan Jalan dan Jembatan & 66 & 29,9 \\
3 & Bangunan Air & 53 & 24,0 \\
4 & Perumahan/Pemukimam & 25 & 11,3 \\
5 & Instalasi/Jaringan Listrik & 4 & 1,8 \\
6 & PDAM & 1 & 0,5 \\
7 & Bandar Udara & 1 & 0,5 \\
8 & Konstruksi Kereta Api & 1 & 0,5 \\
\hline
\end{tabular}

Sumber: Data Olahan (2020)

\section{Proyek Kontruksi yang di Tunda akibat Covid-19}

Berdasarkan survey diketahui bahwa lebih dari separuh proyek responden mengalami penundaan yaitu sebesar 78,9\% seperti terlihat pada gambar 3 dibawah ini.

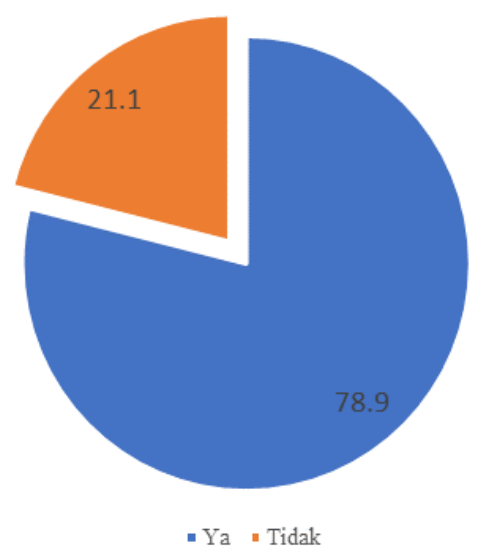

Gambar 3. Jumlah Pekerjaan Konstruksi yang Tertunda akibat Covid-19 
Lamanya penundaan proyek yaitu rata-rata 1-3 bulan, sebesar 31,85\%. Data lamanya waktu penundaan dapat dilihat pada Grafik di bawah ini:

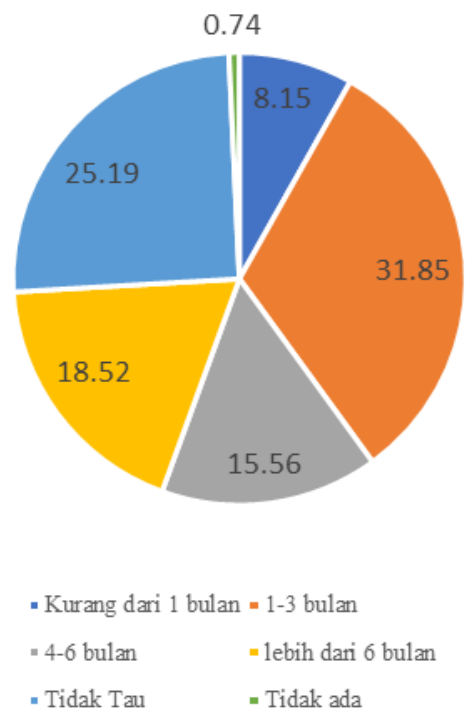

Gambar 4. Lamanya Penundaan Pekerjaan Konstruksi

Penundaan ini terjadi karena banyak aturan baru yang dibuat oleh pemerintah, sehingga banyak penyesuaian yang harus dilakukan. Beberapa hal yang mengakibatkan penundaan dapat di lihat pada Tabel 4 berikut:

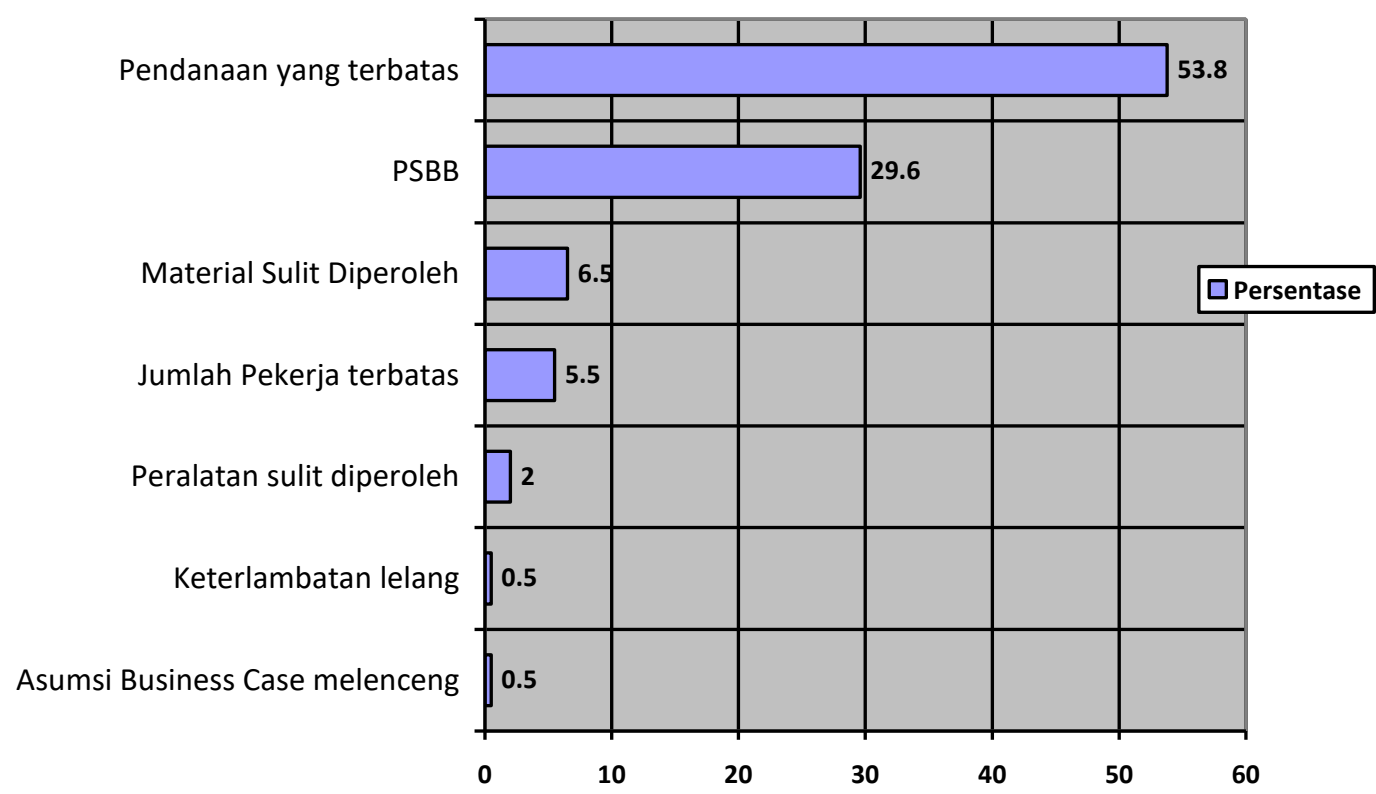

Gambar 5. Penyebab Tertundanya Pekerjaan Konstruksi

Dari Gambar di atas terlihat bahwa penyebab utama penundaan yang paling tinggi yaitu pendanaan yang terbatas dan PSBB dengan persentase masing-masing adalah 53,8\% dan 29,6\%.

\section{Proyek Kontruksi yang tidak terganggu Covid-19}

Meskipun banyak proyek yang dibatalkan atau ditunda karna Covid-19 ternyata masih ada beberapa proyek yang tetap bisa dilaksanakan sesuai rencana atau tidak terganggu sebesar 23,53\%. Meskipun tidak terganggu dengan wabah Covid-19, pekerjaan konstruksi tersebut tetap menerapkan Protokol Kesehatan sesuai aturan yang berlaku. Sebanyak $88,71 \%$ pekerjaan yang tidak terdampak menerapkan protokol kesehatan dan mengikuti aturan yang dibuat oleh Pemerintah. Selain itu, para personil pekerjaan mendapatkan pengetahuan mengenai Protokol Kesehatan dari berbagai sumber, antara lain $23,64 \%$ diperoleh dari media sosial, $23,53 \%$ dari sosialisasi yang dilakukan oleh pemerintah lalu diperoleh dari media cetak dan elektronik, webinar, surat edaran, dan peraturan perusahaan. Data sumber pengetahuan tentang Protokol Kesehatan dapat dilihat pada gambar 6. 


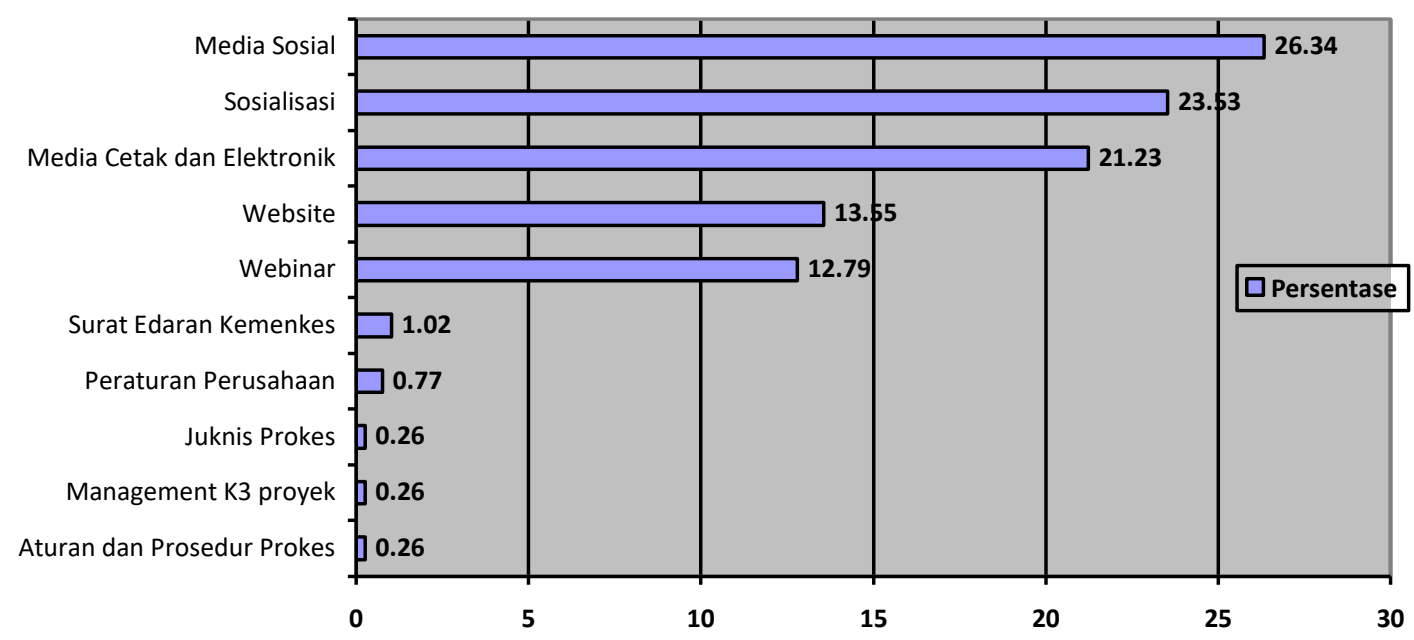

Gambar 6. Sumber Pengetahuan Mengenai Protokol Kesehatan bidang Konstruksi

\section{Dampak Covid-19 Terhadap Para Pekerja Konstruksi}

Pandemi Covid-19 tidak hanya berdampak pada Proyek Konstruksi, tapi juga berdampak pada semua personil yang terlibat dalam proyek tersebut. Dari data yang diperoleh diketahui bahwa dampak yang paling dirasakan yaitu aktifitas menjadi terbatas, komunikasi tidak lancar, hingga kehilangan pekerjaan. Dari gambar di bawah ini dapat diketahui lebih detail dampak apa saja yang terjadi pada para pekerja konstruksi.

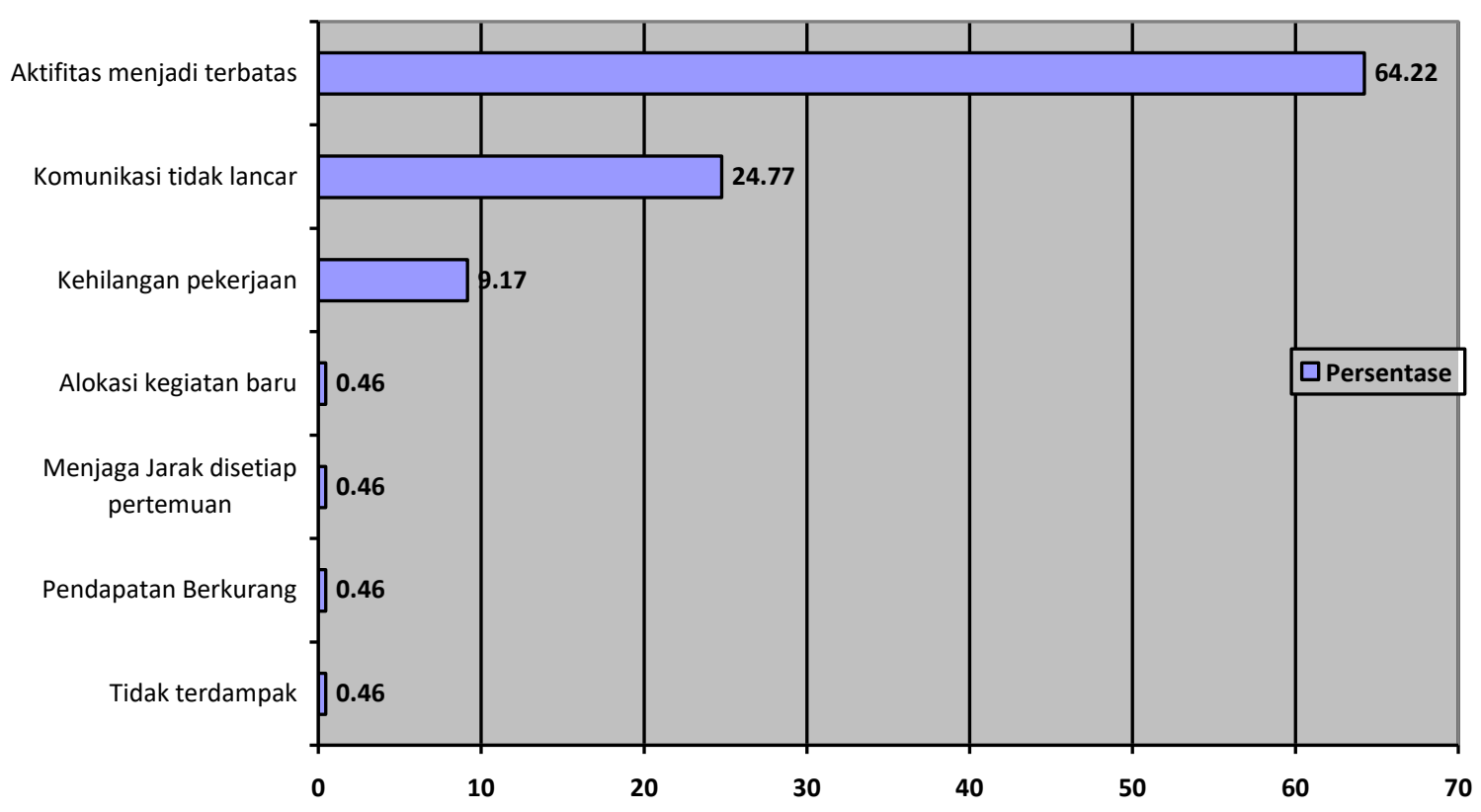

Gambar 9. Dampak Pandemi Covid-19 terhadap Pekerja Konstruksi

\section{Pembahasan}

Dari penelitian yang telah dilakukan oleh Deshariyanto (2013) mengenai faktor-faktor yang mempengaruhi waktu pelaksanaan proyek diketahui bahwa keuangan merupakan salah satu faktor yang dapat membuat pekerjaan konstruksi berjalan dengan lancar, sedangkan saat pandemi Covid-19 terjadi Pemerintah membuat kebijakan untuk memangkas sebagian dana di semua aspek, Presiden Joko Widodo mengeluarkan "Peraturan Pemerintah Pengganti Undang-Undang (Perppu) Nomor 1 tahun 2020 mengenai Kebijakan Keuangan Negara dan Stabilitas Sistem Keuangan untuk Penanganan Pandemi Corona Virus Disease 2019 (COVID-19) dan/atau dalam rangka menghadapi Ancaman yang membahayakan Perekonomian Nasional dan/atau Stabilitas Sistem Keuangan".

Dengan adanya peraturan tersebut, para pelaku konstruksi harus membuat rencana ulang dengan dana yang tersisa dan ini otomatis mengakibatkan penundaan pekerjaan. Lalu kebijakan Pembatasan Sosial Berskala Besar berimbas pada pengurangan jumlah personil dan pengurangan waktu kerja dilapangan. Jumlah pekerja yang dibatasi 
terkait dengan adanya peraturan mengenai Pembatasan Sosial Berskala Besar, Pemerintah Daerah dan Pemerintah Pusat mengeluarkan aturan agar kegiatan bertatap muka dikurangi, untuk mengurangi kemungkinan tertularnya penyakit Corona, sedangkan dari segi material diketahui bahwa suatu proyek akan berjalan dengan baik apabila material dapat disediakan tepat waktu. Selaras dengan penelitian yang dilakukan oleh Randy Putra Agritama, Miftahul Huda, (2018) yang menyimpulkan bahwa salah satu dari 5 faktor penyebab terlambatnya pekerjaan konstruksi adalah keterlambatan pengiriman material, sedangkan pada saat pandemi, aturan PSBB mengakibatkan material sulit didatangkan tepat waktu. Hal ini juga mengakibatkan para pelaku konstruksi harus mengatur ulang jumlah personil dan jam kerja menyesuaikan dengan aturan yang berlaku. Aturan PSBB yang mengatur pengurangan jumlah tatap muka juga berimbas pada kegiatan lelang. Kegiatan lelang yang semula dilakukan secara tatap muka dialihkan melalui daring.

Selain itu, ada beberapa proyek yang tidak terdampak dengan adanya pandemik Covid-19. Proyek yang tidak terdampak ini tetap menjaga protokel kesehatan, sesuai dengan Parinduri dan Parinduri (2020) bahwa penerapan protokol kesehatan dalam K3 konstruksi dapat meningkatkan efisien dan efektif dalam masa pandemi covid-19. Pengetahuan penerapan protokol kesehatan juga didapatkan pekerja konstruksi dari berbagai sumber. Media sosial menjadi sumber yang paling banyak digunakan oleh pekerja industri konstruksi untuk mendapatkan pengetahuan tentang protokol kesehatan yang diterapkan selama pandemi. Ini juga tertuang dalam penelitian Purbohastuti (2017) bahwa sosial media merupakan wadah yang efektif dalam menyampaikan informasi dan promosi. Dampak pandemi juga dirasakan secara personal pekerja konstruksi. Keterbatasan melakukan aktifitas adalah dampak signifikan yang dirasakan oleh pekerja konstruksi.

\section{SIMPULAN}

Dari data yang telah dikumpulkan, hasil penelitian serta pembahasan dapat ditarik beberapa kesimpulan, yaitu sebagai berikut:

1. Pandemi Covid-19 sangat berdampak terhadap dunia Konstruksi, berdasarkan hasil survei terhadap 166 responden diketahui bahwa 78,9\% proyek konstruksi Tahun 2020 mengalami penundaan, lamanya penundaan rata-rata 1-3 bulan $(31,85 \%)$. Penyebab utama penundaan yaitu: pendanaan yang terbatas $(53,8 \%)$, PSBB $(29,6 \%)$, material sulit diperoleh $(6,5 \%)$.

2. Selain ditunda, ada beberapa proyek konstruksi yang tidak terganggu oleh Covid-19 (23,5\%), proyek-proyek yang tidak terganggu adalah proyek untuk pekerjaan vital yang sifatnya darurat, sehingga tidak bisa dibatalkan atau ditunda, namun meskipun tidak terganggu 88,71\% dari proyek tersebut tetap mematuhi Protokol Kesehatan. Ada 92,17\% responden yang menjawab bahwa mereka mendapatkan pengetahuan mengenai Protokol Kesehatan dari tempat kerja. Selain dari tempat kerja, responden memperoleh pengetahuan mengenai Covid-19 dari social media $(26,34 \%)$, sosialisasi $(23,53 \%)$, serta dari media cetak dan elektronik $(21,23 \%)$

3. Covid-19 tidak hanya berdampak pada proyek konstruksi tapi juga berdampak pada semua yang terlibat dalam proyek tersebut, dampaknya yaitu: aktifitas menjadi terbatas (64,22\%), komunikasi menjadi tidak lancar karena adanya aturan yang membatasi tatap muka atau kegiatan yang menimbulkan keramaian $(24,77 \%)$ serta kehilangan pekerjaan $(9,17 \%)$

\section{DAFTAR PUSTAKA}

Creswell, J. W. 1998. Qualitative inquiry and research design: Choosing among five traditions. In Qualitative Health Research (Vol. 9, Issue 5). Sage Publications Inc. http://en.wikipedia.org/wiki/Emic_and_etic

Deshariyanto, D. 2013. Faktor - Faktor Yang Mempengaruhi Waktu Pelaksanaan Proyek Konstruksi Di Dinas Pu. Bina Marga Kabupaten Sumenep. Jurnal Ilmiah MITSU, 1(2), 1-11. https://doi.org/10.24929/ft.v1i2.59

Gamil, D. Y., \& Alhagar, A. 2020. The Impact of Pandemic Crisis on the Survival of Construction Industry : A Case of COVID-19 Dr . Yaser Gamil Abdulsalam Alhagar. Mediterranean Journal of Social Sciences, 2117, 122128.

Hadiwardoyo, W. 2020. Kerugian Ekonomi Nasional Akibat Pandemi Covid-19 [National Economic Losses Due to the Covid-19 Pandemic]. Baskara Journal of Business and Enterpreneurship, 2(2), 83-92. https://doi.org/10.24853/baskara.2.2.83-92

Hassan, H., Mangare, J. B., \& Pratasis, P. A. K. 2016. Konstruksi Dan Alternatif Penyelesaiannya ( Studi Kasus : Di Manado Town Square Iii ). Jurnal Sipil Statik, 4(11), 657-644.

Jallow, H., Renukappa, S., \& Suresh, S. 2020. The impact of COVID-19 outbreak on United Kingdom infrastructure sector. Smart and Sustainable Built Environment. https://doi.org/10.1108/SASBE-05-2020-0068

Kurniawan, F., Wulandari, D. A. R., \& Ayu, L. A. 2018. Studi Kasus Keterlambatan Proyek Konstruksi Di Provinsi Jawa Timur Berdasarkan Kontrak Kerja. Narotama Jurnal Teknik Sipil, 2(2 (November 2018)), 21-31.

Maddeppungeng, A., Intari, D. E., \& Oktafiani, A. 2020. Studi Faktor Penyebab Keterlambatan Proyek Konstruksi Studi Kasus Proyek Pembangunan 6 Ruas Jalan Tol Dalam Kota Jakarta. Konstruksia, 11(1), 89. 
https://doi.org/10.24853/jk.11.1.89-96

Nasution, D. A. D., Erlina, E., \& Muda, I. 2020. Dampak Pandemi COVID-19 terhadap Perekonomian Indonesia. Jurnal Benefita, 5(2), 212. https://doi.org/10.22216/jbe.v5i2.5313

Parinduri, L., \& Parinduri, T. 2020. Implementasi Manajemen Keselamatan Konstruksi Dalam Pandemi Covid 19. Buletin Utama Teknik, 15(3), 222-228.

Purbohastuti, A. W. 2017. Efektivitas Media Sosial Sebagai Media Promosi. Tirtayasa Ekonomika, 12(2), 212-231

Randy Putra Agritama, Miftahul Huda, T. S. R. (2018). Faktor - Faktor Yang Mempengaruhi Keterlambatan Proyek Konstruksi Di Surabaya. Axial, Jurnal Rekayasa Dan Manajemen Konstruksi, Vol 6 No.1(1), 25-32.

Russefendi, E. T. (2010). Dasar-Dasar Penelitian Pendidikan dan Bidang NonEksakta Lainnya. Tarsito.

Sugiyono. (2016). Metode Penelitian Kuantitatif, Kualitatif dan R\&D. PT Alfabet.

Yamali, F. R., \& Putri, R. N. (2020). Dampak Pandemi Covid-19 Terhadap Ekonomi Indonesia. Ekonomis: Journal of Economics and Business, 4(2), 384-388. https://doi.org/10.33087/ekonomis.v4i2.179 